\title{
Effect of Use of Different Types of Materials in Car Interior Parts on Parts
} Assembly and Perceived Quality

\author{
${ }^{* 1}$ Huseyin Çağrı Sütcü ${ }^{1}$ İlker Ertürk \\ ${ }^{1}$ TOFAŞ, R\&D, Perceived Quality, Ergonomics \& Style Section Administration, Bursa, Türkiye
}

\begin{abstract}
In the automotive industry, where perceived quality is of paramount importance, plastic pins and plastic hole mounting types are generally used in vehicle interior components. Two components made of the same material, production and assembly can be performed by assuming equal pin-hole tolerances. In this article, there are geometric dimensioning and tolerance engineering studies aiming to increase perceived quality in the issues of assembly, visibility, sound and interference that may arise from differences in the tolerance of pin-hole sizes between the pin made of magnesium and the hole made of polypropylene. In this context, visibility and interference analyzes were carried out in virtual environment for problems that may arise from tolerance differences.
\end{abstract}

Keywords: Perceived quality, geometric dimensioning and tolerancing, automotive, interference, gap and flush

\section{Özet}

Algılanan kalitenin büyük önem taşıdığı otomotiv endüstrisinde, araç iç kabininde bulunan komponentlerin montajı sırasında birbirlerine referanslayabilmek için genellikle plastik pim ve plastik delik yapıları kullanılmaktadır. Aynı malzemeden imal edilmiş iki komponentin, pim ve deliklerinin boyut toleransları eşit olduğu varsayılarak birbirlerine montajı yapılabilmektedir. Bu bildiride, magnezyum alaşımlı malzemeden üretilmiş pim ile plastik malzemeden üretilmiş delik arasındaki pim ve delik boyutlarının, tolerans farklılıklarından dolayı kaynaklanabilecek montaj, görünürlük, ses ve girişim problemlerine karşı algılanan kaliteyi artırmaya yönelik geometrik boyutlandırma ve toleranslandırma çalışmaları yer almaktadır. Bu kapsamda, tolerans farklılıkları sebebiyle meydana gelebilecek boyutsal değişimler gözetilerek pim ve delik arasındaki uygun referanslama boşluğunun belirlenmesine yönelik mesafe ve girişim analizleri yapılmıştır.

Anahtar Kelimeler: Algılanan kalite, geometrik ölçülendirme ve toleranslandırma, otomotiv, girişim, boşluk ve profil

\section{Introduction}

The biggest factor in the success of a vehicle in the automotive industry is customer satisfaction, and manufacturers who want to find a place in the market can achieve this success by considering customer requirements. Perceived quality is responsible for defining the requirements and requirement levels that determine customers' impression of the car's quality. Perceived quality is the first thing customers perceive. Hence, it differs from a few related concepts.

- Real or objective quality: the degree to which the product or service delivers superior service

- Product-based quality: nature and quantity of ingredients, features or services included

- Production quality: conformity to specification, "zero defect" target.

*Corresponding author: Address: TOFAŞ, R\&D, Perceived Quality, Ergonomics \& Style Section Administration, Bursa, TURKEY. E-mail address: Cagri.Sutcu @ tofas.com.tr, Phone: +905496948724 
The group of engineers responsible for the perceived qualitycom petence area define requirements for design and engineering, then predict issues, verify engineering solutions, and evaluate design status until the final sign-off. This is a continual iterative process, as one issue can be solved while a new one can occur [1].

In order to increase the quality monitoring on the customer, dimensional engineering works in this area to not reflect the elements such as gap flush interference and visibility to the customer. Dimensional engineering is a discipline that includes design, production, assembly and customer satisfaction. In these engineering studies, production, assembly and customer satisfaction are taken into consideration during the design phase and the design is developed accordingly. At this point, the reference strategy of a part is of great importance on functionality and perceived quality. "There are a number of different ways to locate parts, i.e. locating schemes. One common way is the 3-21 system where 6 theoretical points are used to lock the six degrees of freedom, three translations and three rotations, see figure 1 . The first three points form a plane that locks two rotations and one translation. The next two points form a line that locks one rotation and one translation and the last point locks the resulting translation. The positioning points are realised by holes, slots, screws for example. Likewise is there six locator points at a target locating scheme."

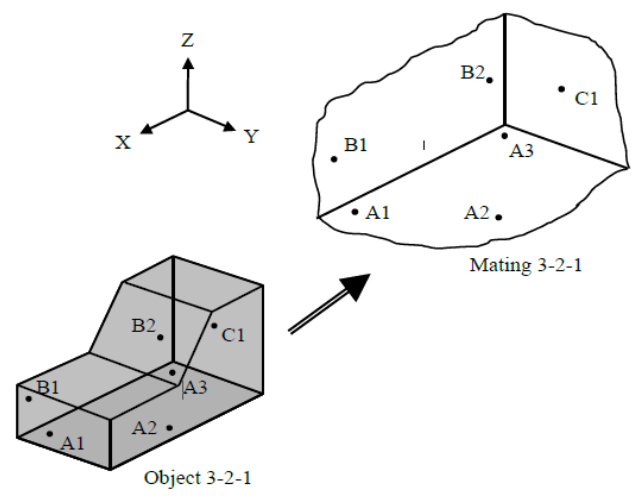

Figure 1. The 3-2-1 locating scheme [2]

The reference strategy targets the limits accepted from the customer point of view and applies the assembly within the appropriate tolerance values [2] [3].

\section{Concept of Pin/Hole}

Pin and hole structures (figure 2) are one of the methods of joining plastic parts. Unless otherwise specified in internal parts, plastic pin and plastic hole size tolerances are accepted as $+/-0.1 \mathrm{~mm}$. Based on this information, the amount of space between the pin and the hole to be referenced should be determined at a suitable value for the reference to work. 


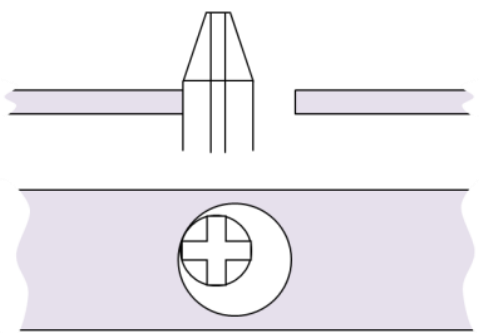

Figure 2. Pin/hole structure.

Another important point to be determined here is to choose the axial direction to be referenced. For example, if reference is to be made in the $\mathrm{X}$ direction according to the vehicle coordinate system, it is necessary to provide the reference clearance in the $\mathrm{X}$ direction in the pin hole matching to be referenced here, while the same reference clearance should not be used in the other Cartesian direction. Here, the Cartesian clearance in the Y direction should be chosen at a larger value than the clearance in the $\mathrm{X}$ direction. If it is desired to make a reference in the $\mathrm{Y}$ direction, this time the clearance in the $X$ direction should be chosen to a larger size than the reference clearance specified in the Y direction. However, the same reference clearance can be used when it is desired to make a reference in both the $\mathrm{X}$ and $\mathrm{Y}$ direction.(figure 3)
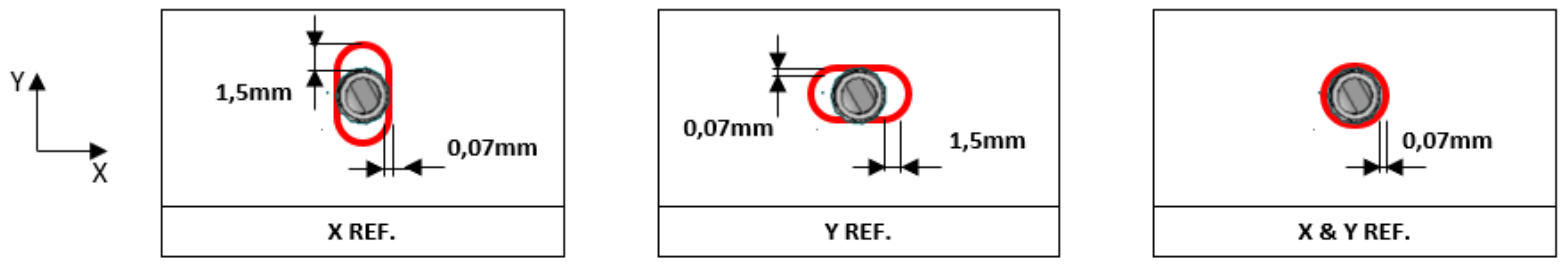

Figure 3. Pin/hole reference examples

For example, if two structures are plastic in pin hole matching, the pin will float in the hole depending on the amount of reference clearance. It can float in the pin hole in 2 different ways, constant and uniform. (figure 4)

Constant float: Pin is always in contact with Hole- Float scattered at $360^{\circ}$

Uniform float: Pin can take every position inside of the hole with an equal probability

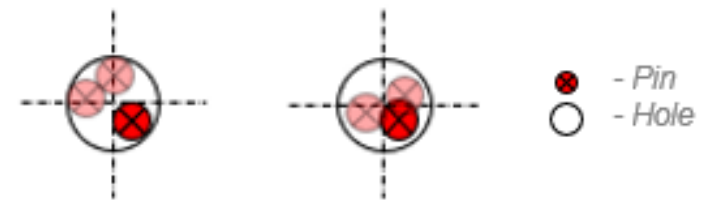

Constant Float Uniform Float

Figure 4. Pin/hole floating types 


\subsection{Comparison Float And Interference According To Size Tolerances And Clearances}

Case 1: Pin and hole are plastic material and have $+/-0.1 \mathrm{~mm}$ size tolerance. Clearance is 0.07 $\mathrm{mm}$;

If we want the pin to be positioned in the hole in accordance with the reference strategy, we need to determine the amount of clearance that will allow the pin to float in the hole in the appropriate amount. As an assumption, let's examine the situation where the pin size is $10 \mathrm{~mm}$, the hole size is $10.14 \mathrm{~mm}$ and the amount of clearance is $0.07 \mathrm{~mm}$. Considering that the pin and hole material is plastic, we can calculate how the pin will float in the hole according to a tolerance of $+/-0.1$ $\mathrm{mm}$.
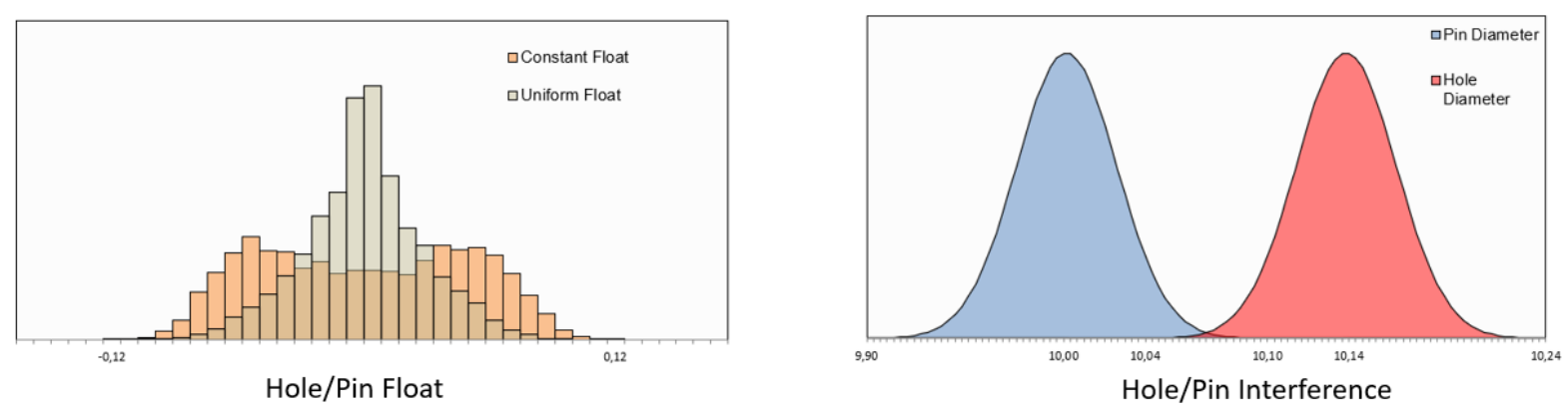

Figure 5. Hole/ Pin Float and Interference for Plastic with $+/-0.1 \mathrm{~mm}$ size tolerances. Clearance is $0,07 \mathrm{~mm}$

As can be seen in this example, the maximum float diameter is $+/-0.17 \mathrm{~mm}$ and the maximum interference is $0.06 \mathrm{~mm}$. (figure 5)

Case 2: Pin is mangenisum alloy and size tolerance is $+/-0.15 \mathrm{~mm}$ and and hole is plastic material with $+/-0.1 \mathrm{~mm}$. Clearence is $0.07 \mathrm{~mm}$;

If the material of the pin or hole changes, the dimensional tolerance of the pin and hole may also change. In this case, the appropriate amount of floating and interference should be determined. This time, let's examine the floating and interference of the plastic hole with a pin made of magnesium alloy as an example. Let's examine the situation where the pin size is $10 \mathrm{~mm}$, the hole size is $10.14 \mathrm{~mm}$ and the amount of clearance is $0.07 \mathrm{~mm}$. In this example, let's assume that the hole size tolerance is $+/-0.1 \mathrm{~mm}$ and the magnesium alloy pin size tolerance is $+/-0.15 \mathrm{~mm}$. 

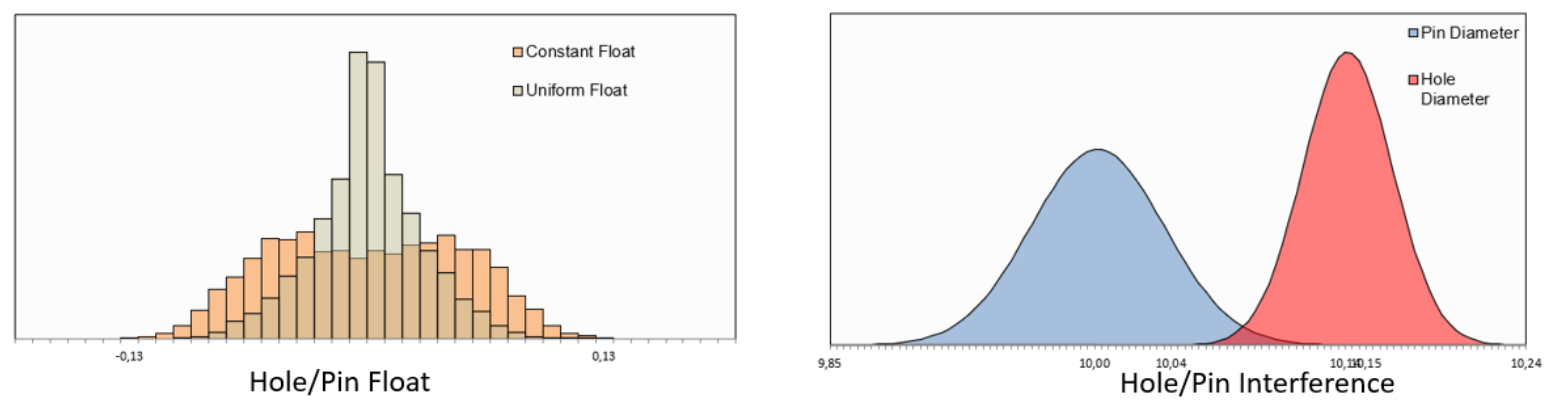

Figure 6. Hole/ Pin Float and Interference for Plastic hole $+/-0.1 \mathrm{~mm}$ and magnesium alloy $+/-0.15 \mathrm{~mm}$ size tolerances. Clearance is $0.07 \mathrm{~mm}$

As can be seen in this example, the maximum float $+/-0.20 \mathrm{~mm}$ diameter, the maximum interference is $0.11 \mathrm{~mm}$. (figure 6) In this case, the amount of possible interference has increased compared to the first example, and the pin and hole may be tightly fitted, damaged in the pin and hole or not attached at all due to the dimensional tolerances during assembly. Such situations can lead to delays in the mass production line and scrapping of parts. To avoid such situations, the appropriate amount of clearances needs to be adjusted at the design stage.

Case 3: Pin is mangenisum alloy and size tolerance is $+/-0.15 \mathrm{~mm}$ and and hole is plastic material with $+/-0.1 \mathrm{~mm}$. Clearance is $0.1 \mathrm{~mm}$

In order to avoid such mounting troubles, it is necessary to determine the appropriate clearance amount when the hole size tolerance is $+/-0.1 \mathrm{~mm}$ and the magnesium alloy pin size tolerance is $+/-0.15 \mathrm{~mm}$. Let's examine the situation where the pin size is $10 \mathrm{~mm}$, the hole size is $10.20 \mathrm{~mm}$ and the gap amount is $0.1 \mathrm{~mm}$.
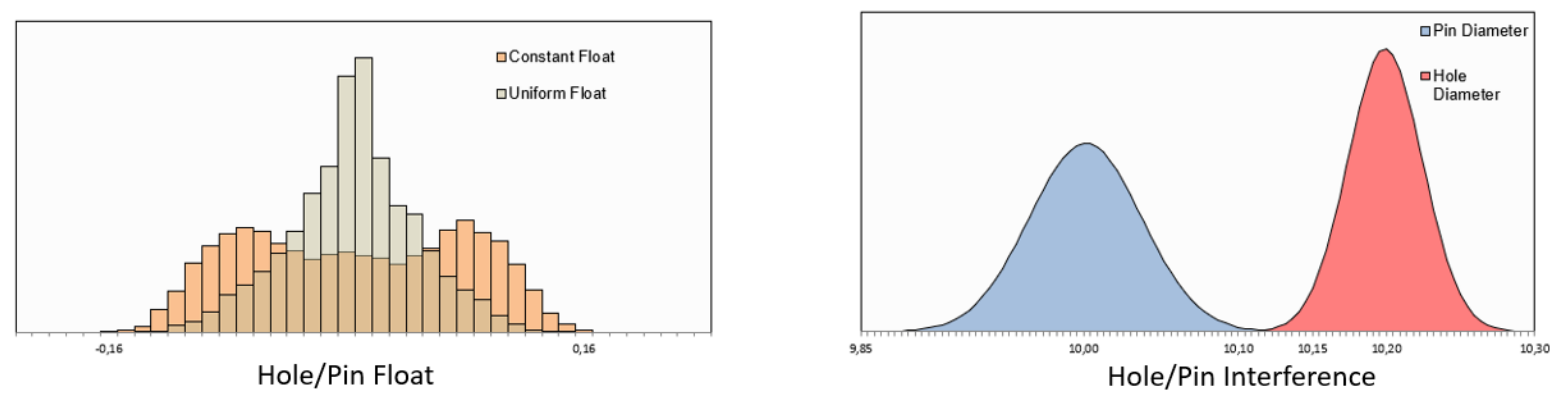

Figure 7. Hole/ Pin Float and Interference for Plastic hole $+/-0.1 \mathrm{~mm}$ and magnesium alloy $+/-0.15 \mathrm{~mm}$ size tolerances. Clearance is $0.1 \mathrm{~mm}$

As can be seen in the last example, the maximum float diameter of $+/-0.23 \mathrm{~mm}$ is the maximum interference $0.05 \mathrm{~mm}$. (figure 7) In this case, the amount of possible interference has decreased compared to the second example. In this way, the risk is expected to be less during assembly. The 
point to be considered here is to make sure that the amount of float will not affect the operation of the reference.

\section{Results}

The gap and flush functional condition (figure 8) on the two parts is composed of an assembly functional condition. The parts assembly is made by translation of one part to the other on the vertical y axis, normal to the weighing plate of the balance, so it is taken as the common y axis of the local references [4].

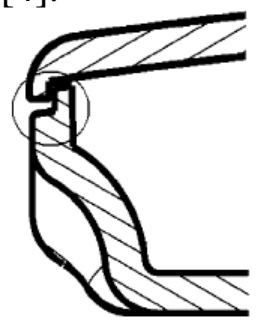

a) Gap and flush

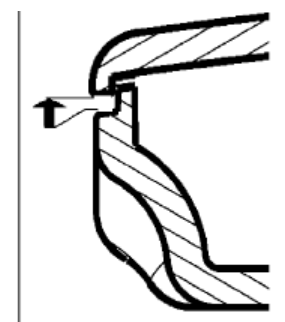

b) The gap

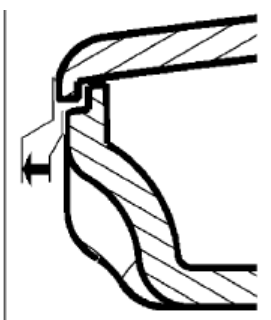

c) The flush

Figure 8. The gap and flush characteristics.

If the appropriate amount of clearance is not determined in pin hole matches, gap mismatch between components can be seen. This can lead to the customer's bad quality perception about the vehicle. (figure 9)

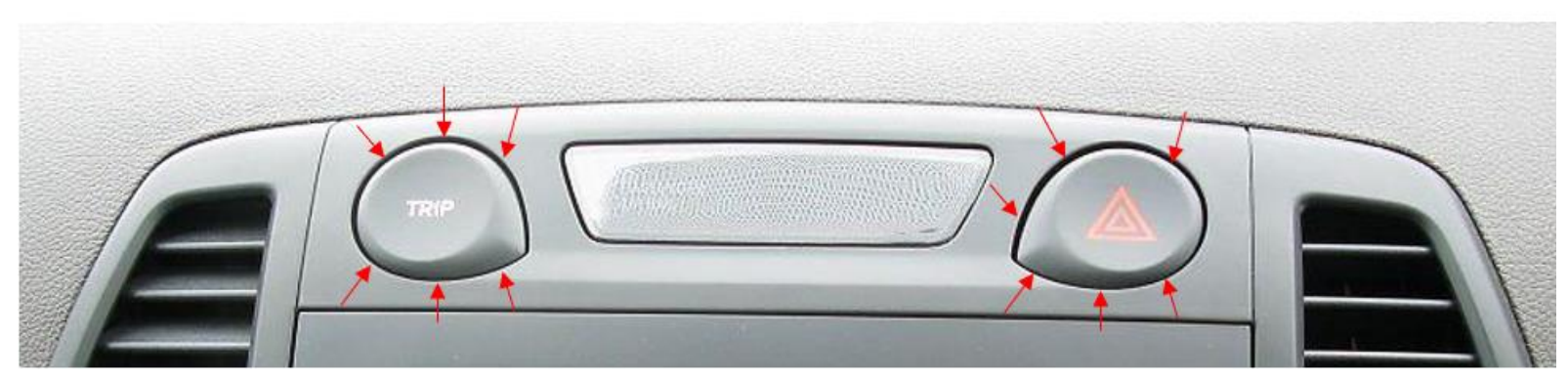

Figure 9. Bad gap perception between components

\section{Conclusions}

In this study, it has been revealed that the appropriate reference gap, which is considered in plastic pin and plastic hole reference matches and determined according to the part size tolerances, can not be used in the same amount of reference gap due to improper interference or floating problems that may occur due to different dimensional tolerances when different types of materials are used. In this research, a detailed analysis was carried out to identify a new reference gap.

As a result, If the appropriate clearance amount is not determined; In addition to mass production 
assembly difficulties and delays, customers may see matches inside the vehicle that may cause a bad physical perception. This can negatively affect the vehicle's reputation.Under these conditions, it is important that the structures to be referenced during part design are determined by the designer with appropriate gap values.

\section{Acknowledgements}

We would like to thank Tofaş R\&D Total Vehicle Integration Manager Murat Ayhaner and Packaging unit administrator Çağrı Mikdan for their organizational supports, Eftal Uygur for perceived quality and Gürkan Yılmazoğlu for material engineering supports.

\section{References}

[1] A. Braun, K. Stylidis, R. Söderberg, Cognitive Quality: An Unexplored Perceived Quality Dimension in the Automotive Industry, CIRP Design, 2020.

[2] A. Dagman, R. Söderberg, C. Wickman, A Study of Customers' and the Automotive Industry's Attitude Regarding Visual Quality Appearance of Split-Lines, ResearchGate, 2004.

[3] Z. Yamaner, E Altikulac, Critical Factor Of Geometric Variation In Perceived Quality: An Engineering Approach, OTEKON, 2016.

[4] P. Adragna, M Pillet, S. Samper, Modal Tolerancing Application To Gap And Flush Analyses, Resarchgate, 2007. 